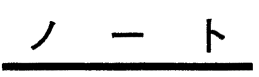

\title{
マレーシア，シンガポール及びタイの市販マーガリン類 の一般性状一とくにパーム油との関連について
}

岡本 隆久*・牛草 寿昭**丸山 武紀*・兼松 弘* 新谷 勋* ·志村 光雄 ${ }^{* *}$

* 財団法人 日本食品油脂検査協会 ( $=103$ 東京都中央区日本橋浜町 3-27-8)

** 日本マーガリン工業会 († 103 東京都中央区日本橋浜町 3-27-8)

General Properties of Commercial Margarines in Malaysia, Singapore and Thailand, Particularly in Relation to Palm Oil

Takahisa OKAMOTO*, Toshiaki USHIKUSA*, Takenori MARUYAMA*, Hiromu KAnematsu*, Isao Niry ${ }^{*}$, and Mitsuo Shimura**

* Japan Institue of Oils \& Fats, Other Foods Inspection, Foundation (3-27-8, NihonbashiHamacho, Chuo-ku, Tokyo)

** Japan Margarines Shortening \& Lard Industries Association (3-27-8, Nihonbashi-Hamacho, Chuo-ku, Tokyo)

For 25 brands of margarines obtained commercially in Malaysia, Singapore and Thailand, general properties were investigated, particularly in regard to tocopherol, tocotrienol, sterol and fatty acid composition, compared to that of palm oil. The samples were 8 brands of domestic margarines including 3 unsaturated (PU) from Malaysia, 9 imported margarines and an imported (Australia 6 including 5 PU, Norway 3) and 2 domestic compound butters from Singapore (Australia: PU) and 4 domestic margarines and a domestic sweet spread from Thailand. Three brands of domestic salad oil (Malaysia 1, Singapore 2) obtained at same time were studied in the same manner.

1) As general components, these margarines generally contained more salt and less milk than those manufactured in Japan. In particular, the 2 domestic samples from Thailand contained no milk. The melting points of the oils separated from the 2 domestic margarines of Thailand and one (PU) of Malaysia were higher than the body temperature. The iodine and saponification values of the separated oils indicated lauric oil such as coconut oil to possibly be blended in all the margarines except PU, and the sweet spread.

2) The analysis of tocopherol, tocotrienol, sterol and fatty acid content indicated the following results. Palm oil is blended in all the margarines except the imported and/or PU, and the salad oil. The oil is the main component of the salad oil of Malaysia. Coconut oil is blended in the domestic margarine but not in $2 \mathrm{PU}$ of Malaysia or 2 of Thailand, the 2 imported margarine (Norway), and the sweet spread. Animal fat though not milk fat is present in 2 domestic (Malaysia 1, Thailand 1) and 3 imported margarines (Australia 1, Norway 2) and 2 PU margarines of Malaysia are manufactured from almost $100 \%$ sunflower oil.

3) Based on the trans-unsaturated fatty acid composition, the proportion of hydrogenated oil blended in the margarines appears to become less with increase in the amount of tropical fat such as palm and coconut oil. 


\section{1 緒言}

オイルパームの中果皮から得られるパーム油は近年そ の生産量が急増し, 植物油脂では大豆油につぐ地位を占 めるようになった ${ }^{1)}$ ２。この急増はオイルパームの育 種による優良品種の植林が栽培適地の東南アジア, とく にマレーシアにおいて展開された結果であり, さらに精 製, 分別など現地での加工技術の進歩によりマーガリン, ショートニングをはじめ多種多様の加工食品の原料油脂 としての利用範讲が拡大したためでもある。

一方, 米国大豆協会はパーム, パーム核及びやし油の ような熱帯産油脂は飽和脂肪で心疾患の危険性があるの で，それらを含む食品に通常の “植物油”と区別できる 特別の表示を義務づけるようにFDA（米連邦食品医薬 品局)に要請し,そのキャンペーンに対する関心が高く, 種々論議されている ${ }^{3)}$.4)。なかでも反論 ${ }^{4)}$ 。おいて, 血清コレステロール值に対する食事脂肪の影響としてよ く引用される実験予測式は健康な成人にも適用できるよ うな確立されたものでないこと，さらにパーム油は飽和 脂肪酸なかでもパルミチン酸を多く含有するにもかかわ らず動脈血栓形成の抑制効果があり，この効果が不けん 化物とくにトコフェロール (Toc) 及びトコトリエノー ル (Toc 3) によることが動物実験で明らかにされたと 指摘されている。

そのような情勢の下で, マレーシア, シンガポール及 びタイで市販されているマーガリン類を入手する機会を 得たので，それらの一般性状とくにパーム油の使用状況 について分析調査し，さきに報告した国産のものら)と比 較，検討したので報告する。

\section{2 実験}

\section{$2 \cdot 1$ 試 料}

試料はマレーシアで入手したマーガリン 8 銘柄（多価 不飽和ソフト 3 , 一般ソフト 5 ), シンガポールで入手し たマーガリン 9 銘柄（多価不飽和ソフト 5 , ハード 4) 及 びコンパウンドバター 2 銘柄, 並びにタイで入手した マーガリン 5 銘柄（多価不飽和ソフト 1 , 一般ソフト 3 , ハード1) 及び加糖スプレッド1銘柄である。また参考 試料として 3 銘柄のサラダ油（マレーシア 1 , シンカ ポール2)を追加した。これらはいずれも昭和 62 年 8 月 に現地のスーパーマーケットなどで購入したもので, シ ンガポールのマーガリン（オーストラリア産 6 , ノル ウェ一産 3) 及び夕イの多価不飽和型マーガリン（オー ストラリア産）以外はすべて自国産であった。

\section{$2 \cdot 2$ 方 法}

$2 \cdot 2 \cdot 1$ 一般栄養成分

水分, 脂質は日本農林規格 (JAS) 法 $\left.{ }^{6}\right)$, タンパク質 は Tecator 社製ケルテックオートシステムを用いて得

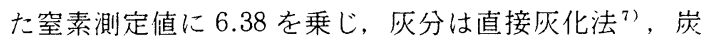
水化物はこれらの合計值を 100 から差し引き, エネル ギーは日本食品標準成分表 ${ }^{8)}$ の換算係数を用いて算出し た。

\section{$2 \cdot 2 \cdot 2$ ビタミン類}

レチノールは JAS 法 ${ }^{6)}, \beta$ 一カロテンはさきに報告し た高速液体クロマトグラフィー (HPLC) 法 ${ }^{9)}$, ビタミ ン $\mathrm{B}_{1}$ はチトクロム蛍光法 ${ }^{7)}, \mathrm{B}_{2}$ はルミフラビン蛍光 法7)で測定した。ビタミン D は試料より得た不けん化 物をジギトニン処理後アルミナカラム ${ }^{10)}$ で分画した D 画分をつぎの条件の HPLC で分析した。カラム：Fine SIL C 18, $4 \times 250 \mathrm{~mm}$, 移動相 : アセトニトリルー水 $(90: 10)$, 流量 $2.0 \mathrm{~mL} / \mathrm{min}$, 検出器: 紫外部吸光光度 計 $(275 \mathrm{~nm})$ 。トコフェロールは試料のへキサン溶液を 硫酸ナトリウム (無水物) で脱水後 HPLC 法 ${ }^{11}$ )で分 析し, 同時に検出されるトコトリエノールは相当するト コフェーロル同族体の検量線を用いて定量した。

\section{$2 \cdot 2 \cdot 3$ 無機成分, 食品添加物及び微生物}

カリウム, ナトリウムは温塩酸抽出, カルシウム, 鉄 は乾式灰化後それぞれ原子吸光光度法 ${ }^{7)}$, リンはモリブ デン青法 ${ }^{7)}$, 銅, 鉛, 七素は基準油脂分析試験法 ${ }^{12)}$, 塩分は $\mathrm{AOAC}$ 法 $^{13)}$ で測定した。食品添加物は保存料 として安息香酸及びソルビン酸, 酸化防止剂としてブチ ルヒドロキシアニソール (BHA) 及びジブチルヒドロキ シトルエン $(\mathrm{BHT})$ をそれぞれガスクロマトグラフィー $(\mathrm{GLC})^{14)}$ で測定した。また微生物検査として, 食品 衛生検査指針の方法 ${ }^{15)}$ に従って一般生菌数, 大腸菌群 及び真菌（かび及び酵母）数を検査した。

$2 \cdot 2 \cdot 4$ 脂肪分の性状

試料から分取した脂肪分の融点 (mp), ヨウ素価 (IV) 及びけん化価 (SV) は基準油脂分析試験法 ${ }^{12)}$, 脂肪酸 組成はシスー,トランス異性体分別条件の $\mathrm{GLC}^{16)}$, ステ ロールはガスクロデー夕小委員会の方法 ${ }^{17)}$ に従って 4デスメチルステロールとして総ステロール含量及びその 組成を測定した。

\section{3 結果及び考察}

\section{$3 \cdot 1$ 一般性状}

各試料及びそれらの脂肪分の一般性状を Table-1に 示す。マーガリンの脂質, 水分, タンパク質, 炭水化物 及び塩分は $82.93,15.04,0.26,0.41$,及び $2.00 \%$ で り, 国産のもの ${ }^{5)}$ 亡比較して塩分が多く，乳成分由来の タンパク質及び炭水化物が少ない傾向がみられ, なかで もマレーシアの No.7, 8 及びタイのNo. 21, 22 には乳 成分がほとんよ゙含まれないことを示した。これは食習慣 や気候・風土の違いによるものであろう。またシンガ ポールの No. 15〜17（いずれもノルウェー産）の水分 は国際規格 ${ }^{18)}$ の $16 \%$ を超えていた。なお, コンパウン 
Table-1 General properties of margarines and salad oils obtained commercially from Malaysia, Singapore and Thailand.

\begin{tabular}{|c|c|c|c|c|c|c|c|c|c|c|c|c|c|c|}
\hline \multirow{2}{*}{$\begin{array}{l}\text { Obtained } \\
\text { from }\end{array}$} & \multirow[b]{2}{*}{ No. } & \multirow{2}{*}{\multicolumn{3}{|c|}{ Kind }} & \multirow[b]{2}{*}{ Pakage } & \multicolumn{5}{|c|}{ General properties } & \multicolumn{3}{|c|}{ Separated oil } & \multirow{2}{*}{$\underset{\substack{\text { Manufac } \\
\text { tured } \\
\text { in }}}{ }$} \\
\hline & & & & & & $\begin{array}{c}\text { Lipid } \\
(\%)\end{array}$ & $\begin{array}{c}\text { Water } \\
(\%)\end{array}$ & $\begin{array}{c}\text { Protein } \\
(\%)\end{array}$ & $\begin{array}{l}\text { Carbohy- } \\
\text { drates (\%) }\end{array}$ & $\begin{array}{l}\text { Salt } \\
(\%)\end{array}$ & $\begin{array}{c}m p \\
\left({ }^{\circ} \mathrm{C}\right)\end{array}$ & IV & SV & \\
\hline Malaysia & 1 & Margarin & (polyz & saturated) & 250 g cup & 81.18 & 15.50 & 0.42 & 0.71 & 2.00 & 31.4 & 102.6 & 192. 6 & Malaysia \\
\hline " & 2 & " & ( & $\prime \prime$ & $\prime \prime$ & 81.50 & 15.21 & 0.39 & 0.67 & 2.06 & 30.2 & 106. 3 & 192.3 & $" \prime$ \\
\hline " & 3 & " & ( & " & " & 81.51 & 15.55 & 0.21 & 0.38 & 2.22 & 38.3 & 101.7 & 198.4 & " \\
\hline " & 4 & " & & & " & 81.22 & 15.63 & 0.40 & 0.75 & 1.83 & 33.6 & 74.9 & 199. 0 & " \\
\hline " & 5 & " & & & " & 81.74 & 15.38 & 0.38 & 0.50 & 1.82 & 34.7 & 66.7 & 201.5 & " \\
\hline " & 6 & " & & & " & 81.80 & 15.67 & 0.21 & 0.37 & 1.82 & 32.4 & 63.0 & 200.5 & " \\
\hline " & 7 & " & & & $250 \mathrm{~g}$ can & 82.35 & 15.53 & 0.03 & 0.05 & 1.96 & 32.9 & 39.1 & 212.9 & " \\
\hline " & 8 & $\prime \prime$ & & & $500 \mathrm{~g}$ can & 82.64 & 15.32 & 0.02 & 0.03 & 1.92 & 33.2 & 39.8 & 211.8 & " \\
\hline Singapore & 9 & Margarin & (polyu & saturated) & $250 \mathrm{~g}$ cup & 81.82 & 15.66 & 0.25 & 0.39 & 1.68 & 32.4 & 110.5 & 193.3 & Australia \\
\hline " & 10 & " & ( & " & " & 81.82 & 14.97 & 0.46 & 0.60 & 1.94 & 31.4 & 95.2 & 194.2 & " \\
\hline " & 11 & " & ( & " & 375 g cup & 81.64 & 15.66 & 0.36 & 0.58 & 1.54 & 32.7 & 104.7 & 193.5 & " \\
\hline " & 12 & " & ( & $"$ & 500 g cup & 81.84 & 14.95 & 0.41 & 0.57 & 2.05 & 30.0 & 107.7 & 194.2 & " \\
\hline " & 13 & " & ( & " & " & 81.24 & 15.73 & 0.39 & 0.54 & 1.93 & 32.2 & 106.2 & 193.7 & " \\
\hline " & 11 & "I & & & $250 \mathrm{~g} \mathrm{~A}$ & 82.42 & 14.34 & 0.34 & 0.54 & 2.20 & 32.9 & 57.1 & 196. 9 & " \\
\hline " & 15 & " & & & $500 \mathrm{~g} \mathrm{~B}$ & 80.58 & 16.39 & 0.15 & 0.22 & 2.54 & 31.3 & 72.6 & 195.3 & Norway \\
\hline " & 16 & " & & & " & 80.44 & 16.45 & 0.13 & 0.28 & 2.57 & 31.3 & 68.3 & 193. 6 & " \\
\hline " & 17 & " & & & $500 \mathrm{~g} \mathrm{~A}$ & 80.85 & 16.61 & 0.13 & 0.25 & 2.04 & 34.1 & 99.0 & 192.0 & " \\
\hline " & 18 & Compoun & butter & & $250 \mathrm{~g} \mathrm{~A}$ & 79. 94 & 15.91 & 0.88 & 1.23 & 1.80 & 28.6 & 35.0 & 222.3 & Singapore \\
\hline " & 19 & " & & & " & 79. 98 & 15.77 & 0.98 & 1.22 & 1.92 & 30.1 & 33.6 & 226.3 & " \\
\hline Thailand & 20 & Margarin & (polyu & saturated) & $250 \mathrm{~g}$ cup & 82.55 & 14.39 & 0.39 & 0.63 & 1.91 & 34.0 & 105.9 & 193.0 & Australia \\
\hline " & 21 & " & & & $15.1 \mathrm{~g}$ cup & 81.91 & 15.78 & 0 & 0 & 2.14 & 30.1 & 8.6 & 249.7 & Thailand \\
\hline " & 22 & " & & & $150 \mathrm{~g}$ cup & 83.33 & 14.57 & 0 & 0 & 1.98 & 35.1 & 13. 1 & 243.8 & " \\
\hline " & 23 & " & & & " & 85.69 & 12.02 & 0.09 & 0.14 & 1.97 & 37.2 & 55.7 & 197.0 & \\
\hline " & 24 & " & & & $450 \mathrm{~g} \mathrm{~B}$ & 82.49 & 14.27 & 0.54 & 0.74 & 1.87 & 42.5 & 56.6 & 199.6 & \\
\hline " & 25 & Spread ( & ceteno & & $150 \mathrm{~g}$ cup & 65.04 & 12.21 & 0 & 20.90 & 1.70 & 32.6 & 8.9 & 249.9 & Thailand \\
\hline Singaporc & 26 & Salad oil & & & $1 \mathrm{~kg} C$ & & 0.10 & & & & $13.0^{\mathrm{D}}$ & 109. 5 & 194.8 & Singapore \\
\hline " & 27 & " & & & " & & 0.08 & & & & $11.3^{\mathrm{D}}$ & 102.8 & 194.3 & " \\
\hline Malaysia & 28 & " & & & " & & 0.14 & & & & $13.2^{\mathrm{D}}$ & 60.4 & 197.9 & Malaysia \\
\hline
\end{tabular}

A : Alminum foil B: Parchment C: Plastic bottle D: Cloud point

ドバターはマーガリンと比べ脂質がやや少ないがタンパ

ク質及び炭水化物はバター配合のため多かった。また, 加糖スプレッドは約 $20 \% の$ 炭水化物（多分糖類）を含 むため脂質が約 $65 \%$ と少ないので，工ネルギーも 680 $\mathrm{kcal} / 100 \mathrm{~g}$ とマーガリン及びコンパウンドバターの平 均 757 及び $745 \mathrm{kcal} / 100 \mathrm{~g}$ より低く, $\mathrm{JAS}^{6)}$ のファッ トスプレッド（加糖）に相当するものであった。

脂肪分の $\mathrm{mp}$ はマーガリン及びコンパウンドバター

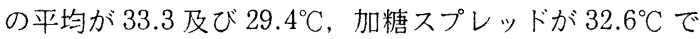
あったが, マレーシアの No.3 及びタイのNo.23, 24 は 体温より高い $\mathrm{mp}$ を示した。マーガリンのIVについて は，多価不飽和型の 95.2 110.5 に対しその他は8.6〜 99.0 之試料間の差が大きく, SVでも多価不飽和型の 192.3〜198.4に対しその他が 192.0 249.7 と同じ傾向 を示した。とくにタイの No. 21，22 は IV が 10 前後で $\mathrm{SV}$ が 240 以上のやし油などのラウリン系油脂の特徴を 示し, 加糖スプレッドのNo. 25 も同様であった。なお,
コンパウンドバターの IV 及び SV は約 34 及び 224 , サ ラダ油の場合はマレーシアのものは 60.4 及び 197.9 之 シンガポール産の 100 以上及び 195 末満とは組成が異な ることを示した。

ビタミン類, ミネラル類, 食品添加物及び微生物検査 の結果については Table-1に入れなかったが, 以下概 要を説明する。ビタミン A は, レチノール不含のマー ガリン 1 銘柄(夕イ) 以外に $\mathrm{A}$ 効力として 1,020 5,270 $\mathrm{IU} / 100 \mathrm{~g}$ (平均 $2,168 \mathrm{IU} / 100 \mathrm{~g}$ ), ビタミン D はマーガ リン 4 銘柄（マレーシア 1 , タイ 3 ) 及びコンパウンドバ ター以外に 160〜2,190 IU/100 g（平均 $779 \mathrm{IU} / 100 \mathrm{~g}$ ) が含ま机, $\beta$ 一カロテンはマーガリン 2 銘柄(ノルウェー 産）以外に使用されていた。ビタミン $\mathrm{B}_{1}$ 及び $\mathrm{B}_{2}$ はマ レーシアの No. 7,8 には $3 \mathrm{mg} / 100 \mathrm{~g}$ 以上及び $5 \mathrm{mg} /$ $100 \mathrm{~g}$ と他のものより著しく多かったが, これらは表示 どおりとくに添加されたものである。その他では, $\mathrm{B}_{2}$ は乳成分が不含または約 $0.2 \%$ のイのNo. 21〜23 以 


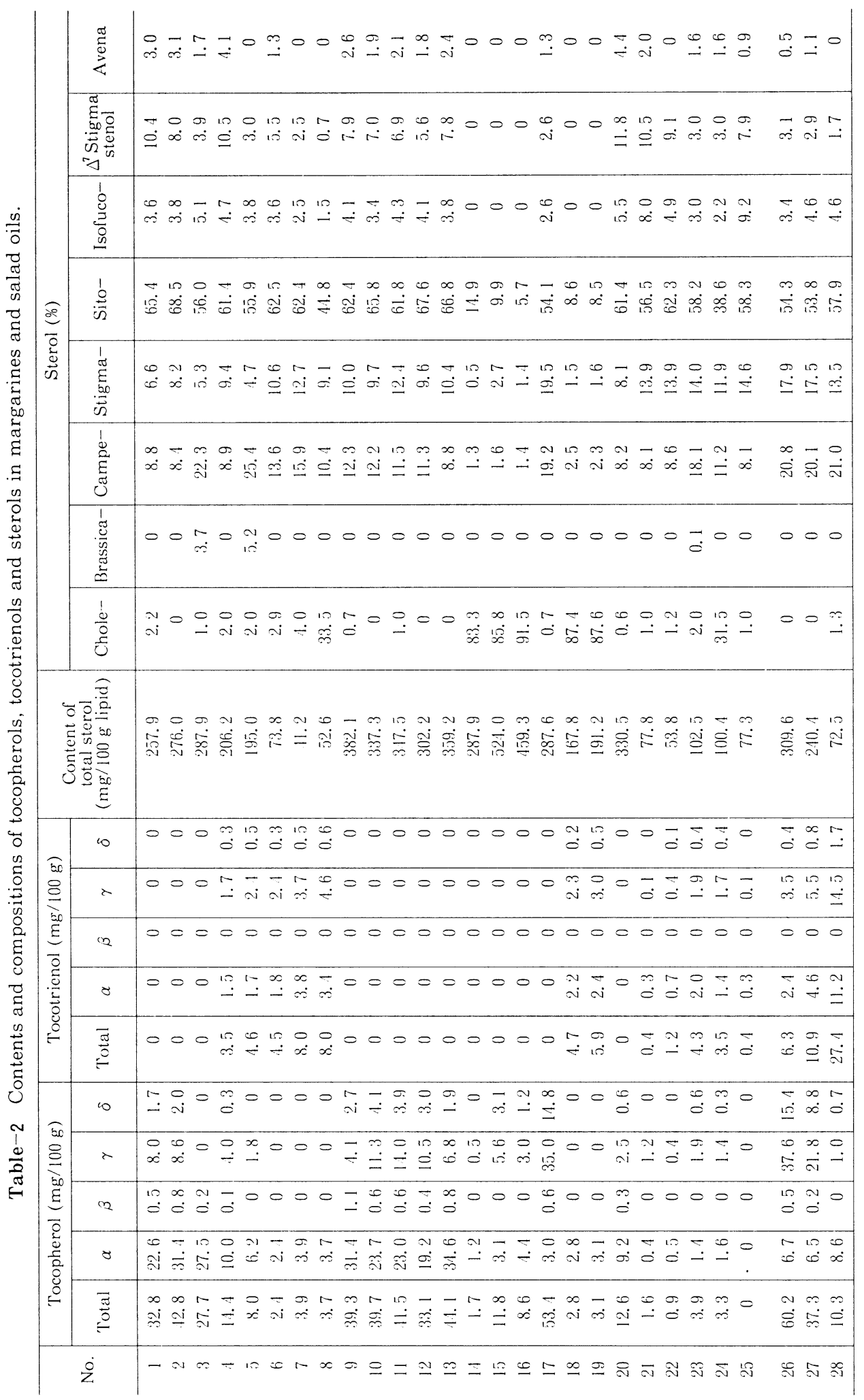


外のマーガリン並びにコンパウンドバターから 0.01〜 $0.06 \mathrm{mg} / 100 \mathrm{~g}$, そのうちマレーシア及びオーストラリ ア産のマーガリン各 3 銘柄並びにコンパウンドバ夕ーか ら0.01 0.03 mg/100 g の $\mathrm{B}_{1}$ も検出されたことから, この両ビタミンは乳成分由来であろう。

ミネラル類のうちナトリウムはマーガリンには 348.0 $\sim 1,110 \mathrm{mg} / 100 \mathrm{~g}$ (平均 $769.7 \mathrm{mg} / 100 \mathrm{~g}$ ), コンパウン ドバター及び加糖スプレッドには約 720 及び $650 \mathrm{mg} /$ $100 \mathrm{~g}$ 含まれ,これらのほとんどは食塩に由来する。マー ガリンには, カルシウムは $3.1 \sim 24.1 \mathrm{mg} / 100 \mathrm{~g}$ (平均 $15.5 \mathrm{mg} / 100 \mathrm{~g}$ ), リンは $0.1 \sim 22.4 \mathrm{mg} / 100 \mathrm{~g}$ (平均 $12.2 \mathrm{mg} / 100 \mathrm{~g}$ ), カリウムは $3.9 \sim 32.6 \mathrm{mg} / 100 \mathrm{~g}$ (平 均 $17.6 \mathrm{mg} / 100 \mathrm{~g}$ ) 含まれたが, 乳成分不含の No. 21 , 22 のカルシウム及びリンは約 3 及び $1 \mathrm{mg} / 100 \mathrm{~g}$ であ るのに対し, バ夕一配合のコンパウンドバ夕ーの場合は それぞれ約 33 及び $26 \mathrm{mg} / 100 \mathrm{~g}$ と多いことからこれら は乳成分に由来すると思われる。な㧊加糖スプレッドの カルシウム, リン及びカリウムは $7.7,1.3$ 及び $13.4 \mathrm{mg} /$ $100 \mathrm{~g}$ 上少なかった。一方, 鉄, 銅, 鉛及びヒ素はマー ガリン及び油脂に対してそれぞれ $1.5,0.1,0.1$ 及び 0.1 $\mathrm{ppm}$ 以下の国際規格 ${ }^{18)}$ がある。マーガリンではNo. 7, 22 の鉄, No. 7, 8 の銅以外, コンパウンドバ夕一で はNo. 19 の鉛以外, 加糖スプレッドでは鉄以外, そし てサラダ油ではNo. 26,27 の鉛以外はいずれも基準に 合致した。

国産 ${ }^{5)}$ では無添加の合成食品添加物のうち酸化防止剂 に関し、マーガリンではマレーシアの 8 試料全部, シン ガポールの 8 試料中 5 試料, タイの 5 試料中 2 試料から $\mathrm{BHA}$, マレーシアの 4 試料, タイの 2 試料から $\mathrm{BHT}$ を 検出した。なお, コンパウンドバター 2 試料から BHA, その 1 試料から BHT も検出したが, 加糖スプレッドか らは検出しなかった。またサラダ油 3 試料中 1 試料から BHA を検出した。合成保存料では, 夕イのマーガリン 1 試料及び加糖スプレッドからのみ息香酸及びソルビ ン酸を検出した。

微生物検查の結果, マーガリンではマレーシアの 2 試 料, シンガポールの 1 試料及びタイの 1 試料から 340 4,400/g の一般細菌を検出したが他はいずれも $300 / \mathrm{g}$ 以 下であり, 大腸菌群は全試料とも陰性で, 真菌も $10 / \mathrm{g}$ 以下であった。

\section{$3 \cdot 2$ Toc, Toc 3 及びステロール}

各試料の Toc, Toc 3及びステロールに関する分析結 果を Table-2に示す。平均値で比較すると, マーガリ ンでは多価不飽和型は総及び $\alpha-T o c$ が 34.8 及び 24.7 $\mathrm{mg} / 100 \mathrm{~g}$ であり, Toc 3 が全く検出されなかったのに 対し，その他は総及び $\alpha$-Toc が 9.0 及び $3.2 \mathrm{mg} / 100 \mathrm{~g}$ と非常に少ないが, Toc 3 はシンガポールの No.14〜17 以外の全試料から検出され, 総量として $4.3 \mathrm{mg} / 100 \mathrm{~g}$
含まれていた。また, 脂質中の総ステロール含量は多価 不飽和型の $320.1 \mathrm{mg} / 100 \mathrm{~g}$ に対し，その他は 189.4 $\mathrm{mg} / 100 \mathrm{~g}$ であり,とくに Toc 3 検出試料は $100.4 \mathrm{mg} /$ $100 \mathrm{~g}$ と少ない傾向を示した。Toc 3 はとうも万こし油

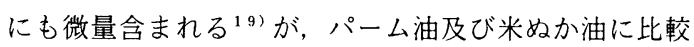
的多量に含まれる11，9)。また，パーム油の総ステロー ル含量は米妨油より相当少ない20)ことから, Toc 3 が検出された 9 銘柄のマーガリンのパーム油使用は明ら かである。同様に Toc 3 を含有したコンパウンドバ夕ー とともに微量ながら検出された加糖スプレッドにもパー 么油配合が考元られる。一方, ステロール組成において コレステロールが $80 \%$ 以上を占めた No. 14〜16 及び $30 \%$ 強の No. 8, 24 には動物油脂の使用が考えられ, ま たバター脂主体のコンパウンドバターもコレステロール が 80 \% 以上を占めた。その他はコレステロールが $5 \%$ 未満之少ないことから原料油脂は植物性のみと思われ, なかでもマレーシアの No. 1, 2 及び 4 はステロール組 成が類似する ${ }^{21)}$ こから $100 \%$ 近いひまわり油と思わ れる。なお, シンガポールのマーガリンNo. 17 は総 Toc が $53.4 \mathrm{mg} / 100 \mathrm{~g}$ ともっとも多いが, その主成分 が $\gamma$-Tocであり, $\delta$-も $\alpha$-Toc より多いことからそ の原料油脂は大豆油 ${ }^{11}$ 主体であり，また加糖スプレッ ドNo. 25 はToc を全く含まないことから, その原料油 脂は Toc を極微量しか含まないやし油 ${ }^{11}$ に少量のパー 么油を加えたものであろう。サラダ油はいずれもパーム 油使用のものを選択したので晴り点も約 $11 \sim 13{ }^{\circ} \mathrm{C}$ とや や高かったが, シンガポールの No. 26, 27 はマレーシ アの No. 28 と比へ,, 総Toc 3 含量は少ないのに対し総

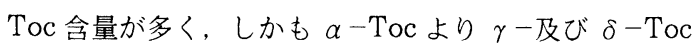
のほうが多いことから大豆油に分別パーム油を配合した ものであり, No. 27 は総 Toc 含量が $10.3 \mathrm{mg} / 100 \mathrm{~g}$ で そのほとんどが $\alpha$-Toc であり, 総ステロール含量も $72.5 \mathrm{mg} / 100 \mathrm{~g}$ と少ないことから逆にパーム油主体の ものと考えられる。

\section{$3 \cdot 3$ 脂肪酸組成}

各試料の脂肪酸組成を Table-3 に示す。動物油脂の 特徵 ${ }^{20)}$ をると, マーガリンではシンガポールの No. 14 16, タイの No. 24 から奇数酸及び $\mathrm{C}_{14: 1}$ が検出さ れ, $\mathrm{C}_{16: 1}$ もやや多いことから動物油脂の存在は明らか で, ステロール組成の結果とも一致した。さらにNo. 15,16 には炭素数 20 以上の高級脂肪酸が多量に存在し たので, 水産動物油脂と思われ, 容器包装の表示之一致 した。しかしステロール組成から動物油脂の存在を推定 したマレーシアNo. 8 の脂肪酸組成にその特徴がみら れなかったのは, 動物油脂を少量しか配合されていない ためと思われる。なお，コンパウンドバ夕ーにも動物油 脂の特徴が認められたのはバー夕脂由来のものであろ う。 
Table-3 Fatty acid compositions of margarines and salad oils.

\begin{tabular}{|c|c|c|c|c|c|c|c|c|c|c|c|c|c|c|c|c|c|c|}
\hline \multirow{3}{*}{ No. } & \multirow{3}{*}{$\begin{array}{l}\text { Kind of material oil } \\
\text { labelled on package } \\
\text { (Predominant) }\end{array}$} & \multicolumn{17}{|c|}{ Fatty acid $(\%)$} \\
\hline & & \multirow[b]{2}{*}{$\leqq 12$} & \multirow[b]{2}{*}{$14: 0$} & \multirow[b]{2}{*}{$14: 1$} & \multirow[b]{2}{*}{$15: 0$} & \multirow[b]{2}{*}{$16: 0$} & \multirow[b]{2}{*}{$16: 1$} & \multirow[b]{2}{*}{$17: 0$} & \multirow[b]{2}{*}{$17: 1$} & \multirow[b]{2}{*}{ 18:0 } & \multicolumn{2}{|c|}{$18: 1$} & \multicolumn{3}{|c|}{$18: 2$} & \multirow[b]{2}{*}{$18: 3$} & \multirow{2}{*}{$20 \leqq$} & \multirow{2}{*}{ Others } \\
\hline & & & & & & & & & & & \begin{tabular}{|c|}
$c-$ \\
\end{tabular} & $t-$ & $c, c-$ & $c, t-t$ & $t, t^{-}$ & & & \\
\hline 1 & & & 0.3 & & & 11.4 & 0.2 & & & 5.9 & 23.1 & 14.2 & 41.3 & 1.5 & 0.5 & 0.4 & 1.2 & \\
\hline 2 & & & 0.3 & & & 11.5 & 0.3 & & & 5.9 & 23.4 & 14.6 & 39.1 & 1.7 & 1.3 & 0.4 & 1.1 & 0.4 \\
\hline 3 & Vegetable & 4. 7 & 1.8 & & & 12.9 & 0.2 & & & 9.6 & 18.9 & 0.3 & 49.5 & 0.9 & & & 0.8 & 0.4 \\
\hline 4 & & 2.7 & 1.4 & & & 27.5 & 0.4 & & & 4.5 & 37.9 . & 3.0 & 18.2 & 0.7 & 0.4 & 1.8 & 1.5 & \\
\hline 5 & Vegetable & 4. 4 & 2.2 & & & 29.3 & 0.4 & & & 3.6 & 41.4 & 0.9 & 13.5 & 0.7 & & 2.3 & 1.3 & \\
\hline 6 & " & 3.0 & 1.9 & & & 33.9 & 0.5 & & & 3.6 & 39.7 & 0.3 & 15.1 & 1.4 & & & 0.6 & \\
\hline 7 & & 14.0 & 5.6 & & & 35.5 & 0.5 & & & 4.5 & 30.4 & 1.1 & 6.8 & 0.5 & & 0.5 & 0.2 & 20.4 \\
\hline 8 & & 13.6 & 5.8 & & & 35.8 & 0.8 & & & 4.8 & 28.8 & 2.2 & 5.9 & 0.7 & 0.4 & 0.1 & 1.0 & 0.1 \\
\hline 9 & Vegetable & & 0.2 & & & 11.1 & 0.2 & & & 6.6 & 19.3 & 12.7 & 45.2 & 1.5 & 1.1 & 0.3 & 1.2 & 0.6 \\
\hline 10 & " & & & & & 12.7 & 0.3 & & & 6.2 & 22.7 & 13.6 & 37.2 & 1.5 & 1.5 & 3.0 & 1.3 & \\
\hline 11 & " & & 0.2 & & & 10.8 & 0.3 & & & 6.8 & 23.4 & 12.6 & 40.7 & 1.2 & 0.9 & 1.9 & 1.2 & \\
\hline 12 & " & & 0.3 & & & 12.4 & 0.3 & & & 5.9 & 22.0 & 13.2 & 38.6 & 1.5 & 1.5 & 2.5 & 1.3 & \begin{tabular}{l|l}
3 & 0.5
\end{tabular} \\
\hline 13 & $"$ & & 0.2 & & & 10.2 & 0.3 & & & 6.9 & 24.3 & 12. 7 & 40.8 & 1.3 & 1.2 & 0.5 & 1.4 & \begin{tabular}{l|l}
4 & 0.2
\end{tabular} \\
\hline 14 & Edible fat & & 2.8 & 0.9 & 0.5 & 21.8 & 3.1 & 1.0 & 0.7 & 15.0 & 37.7 & 3.8 & 7.1 & 1.2 & 1.0 & 0.9 & 0.6 & 1.9 \\
\hline 15 & $\begin{array}{l}\text { Animal, vegetable (marine, } \\
\text { soybean, coconut) }\end{array}$ & 1.3 & 7. 6 & 0.3 & 0.3 & 14.8 & 5.4 & 0.6 & 0.3 & 5.2 & 8.8 & 8.2 & 7.4 & 0.9 & 0.6 & 0.9 & 27.3 & 7.1 \\
\hline 16 & 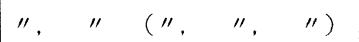 & 4.4 & 8.2 & 0.3 & 0.3 & 14.4 & 7. 1 & 0.6 & 0.4 & 4.1 & 6.6 & 7.2 & 4.2 & 1.1 & 0.4 & 0.5 & 30.5 & 9.7 \\
\hline 17 & Vegetable (soybean) & & & & & 10.8 & 0.2 & & & 8.7 & 25.2 & 19.7 & 27.7 & 1.3 & 0.7 & 4.5 & 1.2 & \\
\hline 18 & Butter oil, vegetable & 10.2 & 7.3 & 0.9 & 0.7 & 36.2 & 2.1 & 0.5 & 0.3 & 8.7 & 24.0 & 1.9 & 3.5 & 0.9 & & 0.5 & 0.5 & 1.8 \\
\hline 19 & Butter, vegetable & 11.6 & 8.0 & 1.1 & 0.7 & 36.1 & 2.9 & 0.5 & 0.3 & 6.0 & 25.1 & 1.0 & 4.1 & 0.4 & & 0.3 & 0.4 & 1.5 \\
\hline$\therefore 0$ & Vegetable & & 0.2 & & & 10.3 & 0.3 & & & 7.6 & 24.4 & 12.0 & 41.3 & 0.7 & & 1.1 & 1.3 & 0.8 \\
\hline 21 & " (coconut, palm) & 54.7 & 16.2 & & & 12. 9 & 0.2 & & & 7.8 & 6.1 & 0.2 & 1.6 & 0.1 & & & 0.2 & \\
\hline 22 & $" \prime$ & 48.0 & 14.7 & & & 16.5 & 0.4 & & & 7.3 & 10.2 & 0.1 & 2.5 & 0.1 & & & 0.2 & \\
\hline 23 & (soybean, palm) & & 0.8 & & & 34.3 & 0.5 & & & 6.7 & 35.6 & 12.9 & 5.5 & 1.4 & 1.0 & & 0.8 & 0.5 \\
\hline 24 & & 0.3 & 1.7 & 0.1 & 0.1 & 36.6 & 1.2 & 0.4 & 0.2 & 9.9 & 32.5 & 1.0 & 11.9 & 1.0 & 0.5 & 1.5 & 0.7 & 0.4 \\
\hline 25 & Vegetable (coconut, palm) & 52.6 & 16.1 & & & 13.0 & 0.6 & & & 8.0 & 6.9 & 0.1 & 1.7 & 0.1 & & 0.2 & & 0.4 \\
\hline 26 & $\begin{array}{l}\text { Soybean, fractionated } \\
\text { palm oil }\end{array}$ & & 0.3 & & & 19. 3 & 0.6 & & & 3.7 & 29.2 & 0.1 & 39.3 & 0.1 & & 6.1 & 1.2 & 0.1 \\
\hline 27 & Liquid palm oil, soybean oil & & 0.4 & & & 20.8 & 0.5 & & & 3.7 & 31.3 & 0.1 & 36.3 & 0.2 & & 5.0 & 1.3 & 0.4 \\
\hline 28 & $\begin{array}{l}\text { Fractionated palm, peanut, } \\
\text { sesame oil }\end{array}$ & 0.1 & 0.9 & & & 36.3 & 1.2 & & & 3.6 & 44.0 & 0.1 & 12.1 & 0.3 & & 0.4 & 0.8 & 0.2 \\
\hline
\end{tabular}

ついで,やし油などのラウンリン系油脂並びに乳脂の 特徴 ${ }^{201}$.22)である炭素数 12 以下の低級脂肪酸をみる と, バター由来のコンパウンドバター以外にその明確な 存在を示したマレーシアのNo. 3〜8, シンガポールの No. 15, 16, 夕イの No. 21, 22 (以上マーガリン) 及び 25 (加糖スプレッド) はラウリン系油脂を使用したもの と考えられる。なかでもNo. 21 及び 25 は 50 \% 以上の 低級脂肪酸を含有し, 表示よ゙おり, やし油を主原料油脂 とするものであり, 48 \%を含むNo. 22 も同様のものと 思われる。

$\mathrm{C}_{18: 2}$ については, 多価不飽和型はいずれも $40 \%$ 以 上を含有し，国産の高リノールソフト型 ${ }^{5}$ に近いタイプ であることを示したが, 最高のマレーシアNo. 3 は約 50 \%を示した。一方, その他ではシンガポールの No. 17 は29.7\%, マレーシアNo. 4〜6, タイ No. 24 は 10〜 20 \%含有したが，その他はいずれも $10 \%$ 未満之国産 ${ }^{5)}$
より相当低い值を示した。なかでも夕イ No. 21,22 及 び 25 は $3 \%$ 未満と非常に低く，これらの $\mathrm{C}_{18: 1}$ 含量も 約 $10 \%$ 以下之低いことからやし油主体の原料油脂使用 が確認された。

また植物油脂では. パーム油 ${ }^{19)}$ に特徵的に多い $\mathrm{C}_{16: 0}$ をみると, マレーシアNo. 6〜8, シンガポール No.18, 19, タイNo.23, 24 はいずれも約 $34 \%$ 以上の高い值を 示し，動物油脂でもっとも多い乳脂 ${ }^{22)}$ のそれより多い ことからパーム油使用が確認された。なお, サラダ油は いずれも動物油脂及びラウリン系油脂の特徴はみられな いが, マレーシアNo. 28 は $\mathrm{C}_{16: 0}$ が $36.3 \%$ とパーム油 の特徴を示したのに対し, シンガポールNo. 26,27 は $\mathrm{C}_{18: 2}$ が $36 \%$ (以上) を示し, 表示どおり大豆油主体の ものと確認された。なおステロール組成でほぼ 100 \% ひ まわり油と推定したマレシーア No. 1, 2 は $\mathrm{C}_{16: 0}$ が約 $11 \%$ に対し炭素数 18 の合計が $85 \%$ 以上を示し, 脂肪 
酸組成 ${ }^{21)}$ でもその推定を確認できたが, No. 4 はやや 異なる組成を示し，他種の存在が考えられる。

硬化油に由来するトランス不飽和脂肪酸に関し平均値 で比較すると，シスー及びトランスー $\mathrm{C}_{18: 1}$ はマーガリ ンでは多価不飽和型が 22.4 及び $11.8 \%$ に対しその他が 26.2 及び $4.4 \%$ であり, $\mathrm{C}_{18: 1}$ 総量にはあまり差がない のに多価不飽和型のほうがトランスー $\mathrm{C}_{18: 1}$ が多い傾向 がみられた。しかし, 多価不飽和型でもやし油の存在を 示したマレーシア No.3 はトランスーC 18 : 1 が $0.3 \%$ しか 存在せず，またその他マーガリンでもシンガポール No. 15 17(以上ノルウェ一産) の場合は平均 $11.7 \%$ で あり,これらにはパーム油もラウリン系油脂も存在しな かった。さらにバ夕ー脂主体でパーム油も使用したコン パウンドバターはシスー及びトランスー $\mathrm{C}_{18: 1}$ が 24.2 及 び $1.5 \%$,やし油主体の加糖スプレッドは 6.9 及び $0.1 \%$, パームオレイン及び植物油から成るサラダ油は 34.8 及 び $0.1 \%$ とトランス酸が非常に少なかった。シス, シス $-\mathrm{C}_{18: 2}$ 及びそのトランス体総量はマーガリンでは多価 不飽和型が 41.5 及び $2.2 \%$ ，その他が 9.8 及び $1.2 \%$, コ ンパウンドバターが 3.8 及び $0.7 \%$, 加糖スプレッドが 1.7 及び $0.1 \%$, サラダ油が 29.2 及び $0.2 \%$ を示した。 マーガリンにおいて総 $\mathrm{C}_{18: 2}$ に対するトランス体の割合 は国産 ${ }^{5)}$ と比較してやや高い傾向がみられるが, $\mathrm{C}_{18: 1}$ の場合より低い点は一致した。

以上の結果, 今回入手したマーガリン類のうちすべて 自国産のマレーシアのものでは多価不飽和型を除く 5 銘 柄, シンガポールのものではすべて輸入品のマーガリン を除く自国産コンパウンドバター 2 銘柄, タイのもので は輸入品の多価不飽和型を除く自国産のマーガリン 5 銘 柄と加糖スプレッド 1 銘柄はすべてパーム油が使用され ていた。また多価不飽和型 1 銘柄を含むマレーシアの 6 銘柄, シンガポールの輸入マーガリン中ノルウェ一産の 2 銘柄及びタイの自国産のマーガリン 2 銘柄と加糖スプ レッド 1 銘柄はラウリン系油脂の使用が認められ，上く にタイ産の 3 銘柄はやし油主体のものであり，国産のも のにはみられない特徵と考えられる。また, 参考として 同時に調查したパームオレイン配合のサラダ油は熱帯地 方特有のものと思われるが，とくにマレーシア産のもの はパームオレイン主体のものであった。パーム油ややし 油のような熱帯産植物油脂の食用としての利用について は．米国大豆協会などから批判1) もあるが, Toc 3 の生 理効果に関する報告 ${ }^{1)}$ ，1ももり，栽培適地の東南アジ アに位置するこ机ら 3 国産のマーガリン類や食用油に使 用さ机ることは当然のことであり，むしろ合理的なこと 亡思われる。
終わりに本報の試料は日本マーガリン工業会のマレー シア・シンガポール視察団に参加し, 現地で購入したも のである。タイの市販マーガリン類をご提供頂いた月島 食品工業株式会社塚本正人研究室長並びにサラダ油をご 提供頂いた日清製油株式会社中島成生氏に深謝致しま す。また本報の分析に協力を得た（財）日本食品油脂検 査協会木下葉子, 村上千秋, 小曰山正剛の諸君に深謝す る。

(昭和 63 年. 2 月 5 日受理)

\section{文献}

1) 加藤秋男, 油化学, 33, 304 (1984)

2) 藤田 匡, 油化学, 35, 342 (1986)

3) From Washington, J. Am. Oil Chem. Soc., 64, 700 (1987)

4) 菅野道廣, 油脂, 46 (10), 48 (1987)

5）兼松 弘, 丸山武紀, 新谷 助, 栄食誌，37，189 (1984)

6) 農林省告示第 522 号, 昭和 29 年 7 月 28 日; 最終收正, 農林水産省告示第 932 号, 炤和 60 年 6 月 22 日

7）日本食品工業学会食品分析法編集委員会編, “食品分析 法”, 光琳 (1982) p. 87, 241, 258, 264, 276, 288, 360, $445,454,860,866$

8）科学技術庁資源調查会編，“四訂日本食品標潗成分表”, 大蔵省印刷局 (1982) p.15

9）丸山武紀, 牛草寿昭, 兼松 弘, 新谷 助, 今村正男, 食衛誌, 18, 487 (1977)

10）日本薬学会編，“衛生試験法注解”，金原计版 (1980) p . 202

11）兼松 弘, 牛草寿炤, 丸山武紀, 新谷 勋, 根大三, 豊田 健, 川口良成, 森井健三, 渡辺㤗, 土肥由長, 町田芳章, 石川雅夫, 松本太郎, 油化学, 31, 456 (1982)

12）日本油化学協会編，“基準油脂分析試験汰”, $2.2 .9 .1 \mathrm{C}$ $77 ; 2.2 .9 .2-77 ; 2.2 .9 .6-77 ; 2.3 .4 .2-71 ; 2.4 .3 .1-71 ; 2$. $4.5 .1-71$

13) A.O.A.C., "Official Methods of Analysis of the Association of Official Analytical Chemists, "A. O.A.C. (1980), p.261

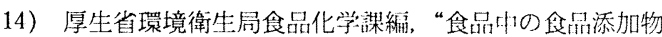
分析法”, 講談社 (1982) p.123, 187, 221

15）厚生省環境衛生舄監修, “食品衛生榆烃指針（I）”，日 本食品衛生協会 (1978) p.103, 107, 150

16）兼松 弘, 丸山武紀，岡本降久，新谷 县，栄咅と食 糧, 34, 551 (1981)

17）ガスクロデータ小委員会編，油化学，30, 307 (1981)

18）国際食糧農業協会編，“国際食品規格”，国際企粕農桠協 会 (1977) p. 油 -5 , 油 -87

19) J.B. Rossel, J.A. Turrell, Food, 8 (3), 35 (1986)

20) 今村正男, 新谷 勋, 丸山武紀, 寺尾尚夫, 食衛誌, 9, 112 (1986)

21）ガスクロデー夕小委員会糄, 油化学，28,932 (1979); 30 $529(1981)$

22）ガスクロデータ小委負会編，油化学，27, 814 (1978) 